\title{
What characteristics affect early voting? The case of Sweden
}

\author{
John Högström ${ }^{1}$ (i)
}

\author{
(c) European Consortium for Political Research 2020
}

\begin{abstract}
In this study, I examine what characteristics affect early voting in Sweden, and a large-N study of all of Sweden's 290 municipalities for the four most recent elections is conducted. The results show that the level of early voting is higher in municipalities where the average income is higher; where the level of older people is higher; where the level of the electorate born abroad is higher; in rural municipalities; and in municipalities where the number of early voting sites per one thousand eligible voters is higher. If the goal of the municipalities is to increase early voting, any policy recommendation that is based on the results of this study should ensure that there are numerous early voting sites in the municipalities and if there are not, the municipalities should consider increasing the number of early voting sites they provide.
\end{abstract}

Keywords Elections · Electoral behaviour · Voting behaviour

\section{Introduction}

Elections play a central role in democracies, and the normal, traditional way of casting a vote in elections is to do so at the polling place on the Election Day. However, in several countries it is possible for citizens to cast their vote at any number of locations prior to the Election Day. Early voting alters the way in which citizens can vote in elections; it makes voting easier and decreases the costs of voting, which should stimulate voter turnout. Accordingly, the theoretical suggestion is that easing the burdens of voting by offering citizens the option to vote early and giving them a choice of locations at which to vote will result in a higher voter turnout. From a democratic perspective, high levels of voter turnout are crucial to the health and quality of democratic systems (Lijphart 1999; Högström 2013). Therefore, it is

John Högström

john.hogstrom@miun.se

1 Department of Humanities and Social Sciences, Mid Sweden University, 83125 Östersund, Sweden 
important to examine which factors affect turnout, and in this study, I will specifically examine which factors affect the variation in levels of early voting.

Previous research on early voting has mostly focused on examining whether early voting affects voter turnout; only a few studies have focused on looking at whether early voting affects satisfaction with vote choice, democracy, and trust (see, for example, Lago and Blais 2019; McAllister and Muller 2018). ${ }^{1}$ A modest body of work, mainly focused on the USA, does exist on alternative voting methods such as early voting and which factors explain the varying levels of early voting. However, the US context, with its low turnout and different forms of early voting among the states (and often within states), is completely different to the contexts in other democracies, so findings regarding the USA may not be generalisable to other contexts (see Walker et al. 2019, for example). Thus, more research that is focused on early voting outside the US context is needed. The main contribution of this study is to examine early voting in a country outside the USA, in this case Sweden, that has a high voter turnout, a long tradition of early voting, and extensive possibilities for its citizens to vote early. The focus of this study is not considering whether early voting affects voter turnout or voter satisfaction. Instead, the focus is examining which factors affect the varying levels of early voting. One research question is posed: what characteristics affect the variation in levels of early voting? To answer the research question, a large-N study of all of Sweden's 290 municipalities for the four most recent elections $(2006,2010,2014$, and 2018) is conducted. In the next section, I will discuss the theoretical points of departure and present a literature review.

\section{Theoretical points of departure and literature review}

The rational choice model of voting suggests that the decision to vote is the result of weighing the collective and individual benefits of voting against the cost of voting (Downs 1957; Riker and Ordeshook 1968). For example, getting to the polls on the Election Day is a cost of voting. According to the model, if the costs are greater than the expected benefits of voting, the rational potential voter will decide not to vote. Thus, the higher the costs, the lower the turnout will be. Potential voters can face different obstacles to voting on the Election Day, such as illness, they are travelling, they are in hospital, they are in a care home for elderly people, they have problems with childcare, they are at work, there is a lack of the transportation needed to get to the polls, there is inclement weather, or they generally have a busy schedule; these can all be factors that prevent citizens from voting on the Election Day. These types of obstacles are also examples of the cost of voting. However, adding extra days and extra voting sites increases the options for when and where voters can cast their votes, and this should decrease the cost of voting. Consequently, early voting methods make it easier for citizens to cast their votes and lower the cost of voting, and

\footnotetext{
${ }^{1}$ For an overview of previous findings on the effect of early voting on voter turnout in the USA (see, for example, Stein and Vonnahme 2011).
} 
therefore turnout rates should increase when early voting is accessible. ${ }^{2}$ There are several alternative voting methods used around the world that give voters the opportunity to cast their vote prior to the Election Day instead of only on the Election Day. Examples of these methods are voting by mail (postal voting), internet voting, and voting early. ${ }^{3}$ As mentioned above, the main purpose of alternative voting is easing the burdens of voting, which will result in citizens voting to a greater extent.

\section{Determinants of early voting}

In relation to the research question, it is relevant to screen what previous research has found affects the level of early voting. Oliver (1996) included data from all of the states of the USA in his study; he found that senior citizens, citizens with a higher income, and citizens with a higher level of education were more likely to be absentee voters. Oliver also demonstrated that rural residents were more likely be early voters than urban ones. Several subsequent studies have confirmed Oliver's results. Stein (1998) examined the Texas gubernatorial election of 1994 and found that early voters were older than Election Day voters. Rojas and Muller (2014) used data from the Australian federal elections; they reported that middle-aged and older Australians cast early votes more often than younger voters. Kropf (2012) included data from eight counties in North Carolina and showed that older individuals were more likely to vote early. McAllister and Muller (2018) investigated the consequences of early voting in Australia and found that older people voted early more often than others did. Garnett (2019) compared early voting in Canada, Finland, Germany, and Switzerland and found that older people were more likely to vote early in all four countries. Karp and Banducci (2001) used data that covered forty-two states in the USA; they also found that older people were more likely to take advantage of absentee laws. Karp and Banducci (2001) demonstrated that having a higher level of education had a positive impact both on voting and on absentee voting. Kropf (2012) found that higher incomes were positively related to early voting. Stein and Garcia-Monet (1997) also found that wealthier voters voted early more often. Garnett (2019) demonstrated that having a post-secondary level of education had a positive impact on early voting in Finland, Germany, and Switzerland.

Several studies have found that disadvantaged groups such as people with a minority ethnic background and foreign-born people vote early more often than others. Stein and Garcia-Monet (1997) examined early voting in the 1992 Texas presidential election and reported that a higher level of people with a minority ethnic background (adult Hispanic population) had a positive impact on early voting. Herron and Smith (2014) focused on early voting in Florida in the 2008 and 2012 elections; they reported that minority voters, in particular black voters, voted early more often than white voters. Miller and Chaturvedi (2018) used survey data from three

\footnotetext{
${ }^{2}$ A negative aspect of early voting is that people who vote early can miss important information that comes out late in the election campaign after they voted.

${ }^{3}$ For an overview of different early voting systems (see, for example, Brothén 2003; Blais et al. 2007; Gronke et al. 2007).
} 
South Atlantic states in the USA and found that black voters were more likely to vote early than white voters. In addition, Kropf (2012) reported that African Americans voted early more often. In a previous study of early voting in Sweden, Dahlberg et al. (2008) reported that foreign-born people voted early more often than people born in their country of residence.

Previous research has also demonstrated that geographic characteristics and accessibility to early voting sites affect early voting. Richardson Jr. and Neeley (1996) examined early voting participation in Tennessee in 1994 and demonstrated that the level of voting site accessibility had a positive impact on early voting in the general election. Dyck and Gimpel (2005) used data from Clark County in Nevada and reported that absentee voting by mail increased as distance to the polling place increased, and they concluded that distance has an impact on the choice of voting method. Dahlberg et al. (2008) demonstrated that having more early voting sites (per eligible voters) had a positive impact on early voting. In a study with a focus on voter turnout in Norwegian municipal elections (1991-2003) and election outcomes, Finseraas and Vernby (2014) found that early voter turnout was higher in rural municipalities than in urban ones. However, the total voter turnout was higher in urban municipalities. Stein and Garcia-Monet (1997) found that an increased number of early voting sites located at non-traditional locations (familiar and frequented locations) had a positive effect on early voting. They also demonstrated that the number of traditional early voting sites (government venues) had no effect on early voting.

Other studies have produced some contradictory results. For example, Neeley and Richardson (2001) found that low-income citizens, older citizens, and people with a minority ethnic background were not more likely to vote early than others. Gronke and Toffey (2008) used data from two national surveys in the USA and did not find any robust factors that differentiated between early and Election Day voters.

To summarise the literature review, there are five main characteristics that previous research on early voting has found affect the level of early voting, namely socio-economic standards (for example income and education), age, belonging to a disadvantaged group (such as people with an ethnic minority background and foreign-born people), living in a rural area, and having increased access to early voting sites. Previous literature has also provided some underlying theoretical reasoning to explain why these factors affect the level of early voting. Older voters can have a problem getting to the polls on the Election Day if there is a lack of public transport or if they are feeling ill, for example, but if voting is more flexible and they can vote prior to the Election Day, there is an increased possibility that they will be able to turn up and vote early and that they will be able to get assistance with transportation to do this if they need it.

From the voter turnout literature, we know that people with higher socio-economic standards vote more often than others (see, Verba and Nie 1972 for example). As mentioned above, previous literature on early voting has also found that people with higher socio-economic standards also vote early more often. The underlying theoretical reasoning that is presented in this literature is a bit vague and not fully convincing, however. For example, it has been suggested that people with a higher level of cognitive recourses (for example those with a higher education level) are better equipped intellectually to use complicated early voting procedures than other 
people are and therefore vote early more often than others (see Garnett 2019, for example).

In rural areas, voters have a longer distance to travel to the polling places and therefore the cost of getting to the polls is higher for them than for voters in urban areas (Dyck and Gimpel 2005; Karp and Banducci 2000). However, if rural voters can combine voting with other errands, for instance shopping or a doctor's appointment, the cost of getting to the polls and voting decreases and therefore rural voters are more likely to vote early to a greater degree than other voters.

Several studies have found that disadvantaged groups such as people with an ethnic minority background and foreign-born people vote early more often than others. Some previous studies have suggested the mobilisation of campaigns as a possible explanation of why these groups of people vote early more often (see, for example, Miller and Chaturvedi 2018; Stein and Garcia-Monet 1997). For example, political parties can use special campaigns to contact people with an ethnic minority background and foreign-born people, and that can affect these groups, leading to early voting. Previous studies have found that people who have been contacted by those involved in running a campaign are more likely to vote (see, Rosenstone and Hansen 1993, for example). Accordingly, parties can use campaigns to encourage particular groups of people to vote early and thus secure votes for their own party. Finally, the theoretical reasoning regarding why an increased level of accessibility to early voting sites should affect early voting is straightforward. If there are an increased amount of accessible early voting locations in an area, the cost of voting decreases and therefore early voting should increase. I will discuss the data and case selection next.

\section{Data and case selection}

\section{The case of Sweden}

As mentioned above, there is a need for more research about early voting outside the context of the USA. In this study, early voting in Sweden will be examined. In comparison with other democracies, Sweden has a high voter turnout and a long tradition of early voting, shown, for example, in the work of Herlitz (1985) and Högström (2013), and therefore I see Sweden as a relevant and interesting case to use for the study of early voting. In addition, there are only a few studies on early voting in Sweden and these studies are relatively old (see, for example, Dahlberg et al. 2008; Brothén 2003), so updating the research on early voting in Sweden also motivates this study.

In Sweden there is a long tradition of local self-government. The municipalities are responsible for important functions in society that often involve carrying out mandatory tasks. All municipalities have the same responsibilities. Examples of the mandatory tasks of the Swedish municipalities are providing social services (including, for example, services for elderly people and services for people with a disability), pre-school services, compulsory and upper-secondary education, environmental protection and public health protection. Local authorities have the right to levy taxes 
to fund carrying out these tasks, and the local authorities decide the actual tax rate. The local income taxes are the main source of revenue for local authorities. The local authorities make their own budget without prior consultation with the central government. From a European comparative perspective, the local government share of the economy is huge in Sweden, and total local government spending represents around 25\% of GDP (Lidström 2016). Accordingly, Swedish local governments have a very important position in Sweden's economy. The municipality elections are not as high profile as the national parliamentary elections, but because the municipalities have so many important functions, the local elections are important elections for the Sweden population.

The local Swedish political system is organised into two tiers below the central government (the upper tier consists of counties and the lower of local-level municipalities). The municipalities have an elected council (Fullmäktige) and a formal executive committee (Kommunstyrelse). Since 1994 the councils have been elected for 4-years terms in popular elections using a proportional electoral system: the adjusted odd-number method (the method of Saint-Laguë with an adjustment of the first divisor (1.4 instead of 1; since the election in 2018, the adjustment of the first divisor has been 1.2). The elections of the three assemblies (national parliament, county councils, and municipal councils) are held on the same day, the second Sunday in September, once every 4 years. The Voting Rights Reform of 1975 granted all residents who lacked Swedish citizenship but who had lived in Sweden for 3 years or more the right to vote in local elections. Accordingly, voting in the county and municipal elections is open to anyone who has lived in Sweden for at least 3 years. The national elections, however, are only open to people with Swedish citizenship.

\section{Early voting in Sweden: an overview}

In Sweden, there are many opportunities to vote in advance, and voters can turn up and cast their votes at specially designated polling places eighteen days prior to the Election Day. Consequently, early voting gives citizens the opportunity to cast their vote on a weekday or a Saturday instead of voting on the second Sunday in September once every 4 years, which is when the Election Day occurs.

The use of alternative voting methods has a long tradition in Sweden, and postal voting was introduced for the first time during the local and regional elections of 1942 (Brothén 2003). At the national level, postal voting was used for the first time in the parliamentary election of the second chamber of the parliament (Riksdagen) in the election of 1944 (Brothén 2003; Ersson and Wide 2001). During the early era of postal voting, it was only citizens who had special reasons not to vote at the polling place on the Election Day who were allowed to vote early at post offices. However, in 1969 parliament extended the possibilities to vote early, and since 1970 Sweden has had a system that allows voters to decide whether they will cast their vote prior to the Election Day or at the polling place on the Election Day (Brothén 2003; Dahlberg et al. 2008; Ersson and Wide 2001; Herlitz 1985). In 2005, the election law transferred the responsibility for organising early voting from the postal company (Posten AB) to the Swedish municipalities. The municipalities were responsible for 
organising early voting for the first time during the elections of 2006, and voters could vote early in, for example, libraries, shops, schools, town halls, or in public offices instead of only being able to vote early at post offices (Dahlberg et al. 2008). The number of locations at which voters can vote early has been increasing in Sweden, and during the elections in 2018 there were more than 2700 locations around Sweden to vote early in. Voters can choose to vote early in any place that offers early voting and they do not need to vote in the same municipality that they live in. Nowadays, early voting is a very popular form of voting and more than $40 \%$ of voters in Sweden vote prior to the Election Day. Before turning to the empirical investigation of early voting in Sweden, I will discuss the empirical strategy and the operationalisation of the variables.

\section{Empirical strategy and operationalisation of the variables}

Using ordinary least squares (OLS) regression, I test a model of early voting. The model examines what factors affect the level of early voting participation. To answer the research question, a large-N study of all of Sweden's 290 municipalities for the four most recent elections $(2006,2010,2014$, and 2018) are conducted; the sample consists of 1159 observations. ${ }^{4}$ Thus, the focus is on the elections of municipal councils. I estimate a pooled, cross-sectional time-series model. Concerning the type of standard errors to use, I follow the suggestion of Beck and Katz (1995) and replace the OLS standard errors with panel-corrected standard errors (PCSEs). The main reason for this is that if heteroscedasticity is present, the OLS standard errors are incorrectly estimated and not trustworthy, but by using the panel-corrected standard errors the OLS standard errors are corrected. In the final model, I also include a lagged dependent variable (a variable measuring early voting at $t-1$ ) with the independent variables (by dropping the panel for 2006 on the dependent variable). ${ }^{5}$ The three multivariate models have been checked with VIF statistics and the models do not indicate any problem with multicollinearity (the VIF value does not exceed 1.9 for any of the variables). It is important to point out that the data that is used in this study is not on the individual level. The data is at the aggregated municipality level and to avoid committing an ecological fallacy inferences at the individual level cannot be drawn (see Brewer and Venaik 2014, for example). To avoid ecological fallacy, only inferences at the aggregated level can be drawn, for example if the composition of the electorate in the municipalities affects the aggregated level of early

\footnotetext{
${ }^{4}$ When I explored the data for the study, I found that the reported level of early voting was abnormally high in the municipality of Bjurholm in the election of 2010 . The reported level was $98.64 \%$ of the total votes cast were early votes. To check whether the reported level of early voting was incorrect, I contacted both the Swedish Election Authority and the municipality of Bjurholm. The Bjurholm municipality confirmed that the reported level of early voting for 2010 was incorrect. Therefore, I removed the data for Bjurholm in 2010 from the data set and therefore the data set consists of 1159 observations rather than 1160 observations.

5 The main reason for including a lagged dependent variable is to eliminate eventual problems with autocorrelation (see Beck and Katz 1996, for example).
} 
voting. The data has mainly been collected from the Swedish Election Authority (2019) and Statistics Sweden (2019).

\section{Dependent variable}

For the analysis, I use one dependent variable: early voting. The measure that is used for early voting is the percentage of the total votes that are cast during the early voting period.

\section{Independent variables}

Based on previous findings, I include five independent variables and examine whether they can explain some of the variation in early voting participation. The first three variables are socio-demographic characteristics. The previous literature has demonstrated that socio-economic standards influence early voting. To control for socio-economic standards, I include a variable that measures the average income. The independent variable average income is the average yearly income per inhabitant (for the age range 20-64 years) in each municipality, and it is measured in thousands of Swedish kronor. It is expected that a higher average income will affect early voting positively. Earlier studies have demonstrated that older citizens vote early more often than younger citizens. Thus, I include an independent variable for age, and the variable measures the percentage of the electorate that is 65 years old or older. I expect that municipalities with a higher level of older voters will have higher early voting rates, and it is therefore expected that the coefficient will be positive. Several studies have found that disadvantaged groups vote early to a greater extent than other groups of voters. Therefore, I include an independent variable that measures the level of disadvantaged groups in the municipalities. In this study I operationalise disadvantaged groups with the level of the electorate who were born abroad, and the variable measures the level of the foreign-born population of the electorate as a percentage. It is expected that a higher level of foreign-born people will have a positive effect on early voting.

The fourth independent variable is a geographic variable. Previous studies have found that early voting is higher in rural areas than in urban areas (see Finseraas and Vernby 2014 for example). I apply a dummy variable for rural municipalities, where rural municipalities are coded 1 and urban municipalities are coded 0 . There are several alternatives that can be used to categorise rural municipalities. In this study I follow a suggestion made by the Swedish Association of Local Authorities and Regions and define a rural municipality as a municipality that has less than seven inhabitants per square kilometre and less than twenty thousand inhabitants in total. Accordingly, both criteria must be fulfilled if a municipality is to be classified as a rural municipality. I expect that rural municipalities will have a higher early voting turnout than urban municipalities, and therefore it is expected that the coefficient will be positive.

Finally, I include a variable that measures accessibility. The variable measures the number of early voting sites per one thousand eligible voters in each municipality. I 


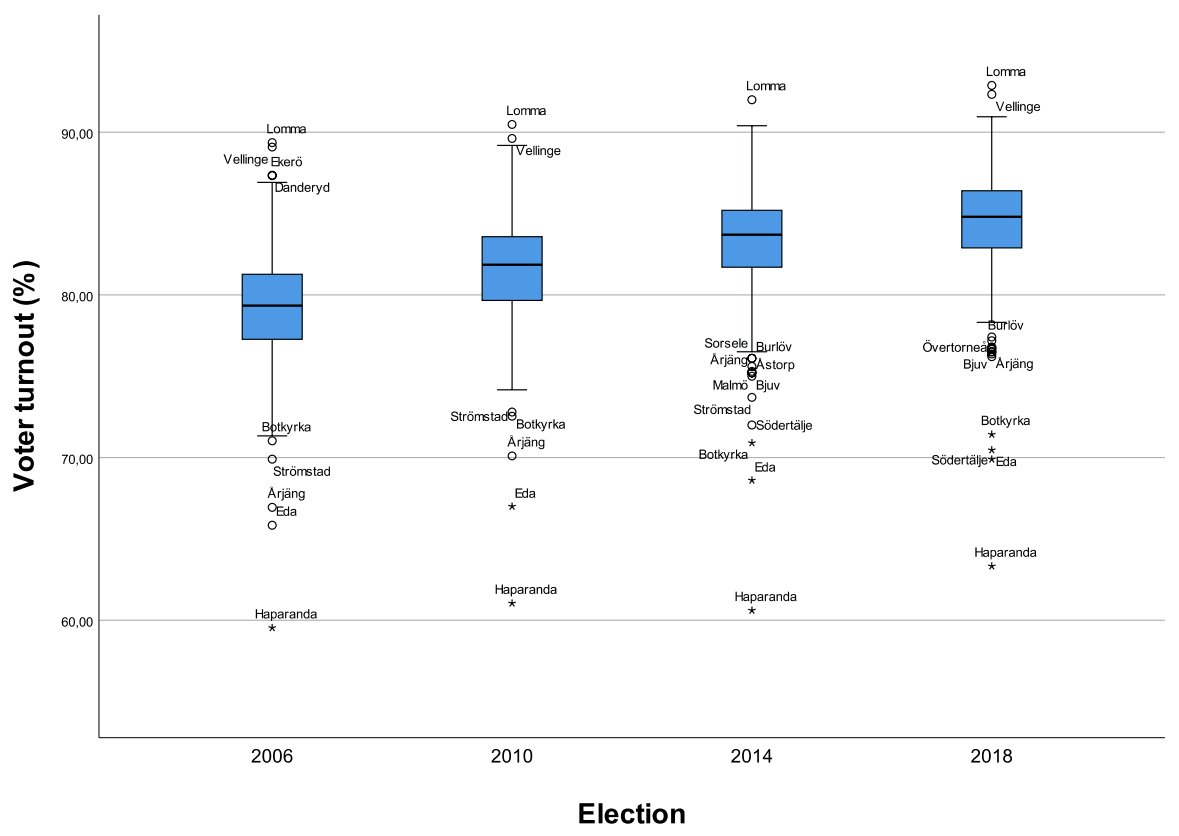

Fig. 1 Voter turnout in the Swedish municipalities 2006-2018

expect that the number of early voting sites (per eligible voters) will have a positive impact on the level of early voting. Table 2 in the appendix presents descriptive statistics for the independent variables that are included in the study. A correlation matrix with the four quantitative independent variables is presented in Table 3 in the appendix will now turn to the analysis and findings.

\section{Analysis and findings}

\section{Mapping voter turnout and early voting}

Before starting the multivariate analyses, I will map voter turnout and early voting. The main focus of this study is not turnout, but before proceeding to the analysis of early voting, it is relevant to present an overview of the voter turnout at the municipality level in Sweden. The box-and-whisker plot in Fig. 1 illustrate the distribution of voter turnout in the Swedish municipalities for the four elections held between 2006 and 2018.

As shown in Fig. 1, the mean turnout increased at the local level in Sweden from $79.28 \%$ in 2006 to $84.33 \%$ in 2018 . Accordingly, the turnout increased by $5 \%$ units during the period 2006-2018. As also shown in Fig. 1, there is a big difference in voter turnout rates between municipalities, and the turnout ranges between 59.53 and $92.88 \%$. Accordingly, there are some municipalities that have a low turnout, but 


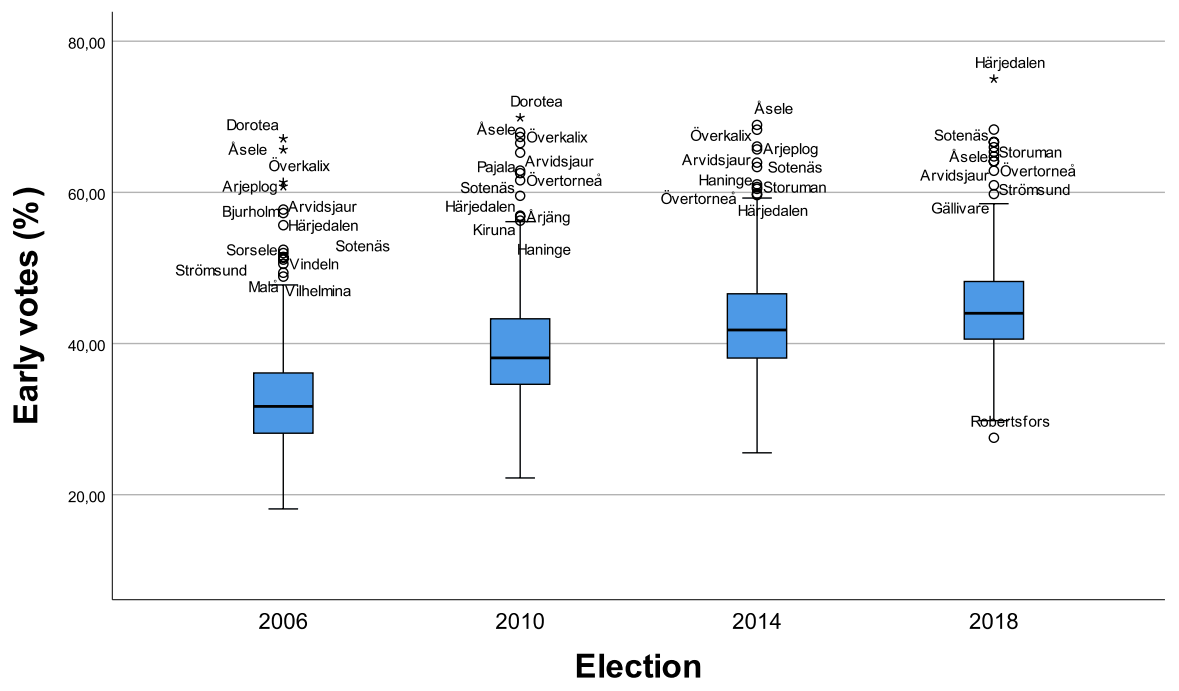

Fig. 2 Early voting in the Swedish municipalities 2006-2018

at the same time, there are municipalities that have a turnout of around $90 \%$. Such high turnout rates in a political environment that does not use compulsory voting is uncommon and also impressive. Following next, Fig. 2 presents a box-and-whisker plot to illustrate the distribution of early voting and shows the percentage of the total votes that are cast during the early voting period.

As Fig. 2 shows, in the election in 2006, 33.13\% of the total votes were early votes and the level of early votes increased in the 2010 election $(39.73 \%)$, in the 2014 election (42.81\%), and in the 2018 election (44.96\%). Accordingly, there was an upward trend in early voting in Sweden and the mean for early voting increased almost $12 \%$ units during the period 2006-2018; in many municipalities' elections more than half of those participating in the municipal elections chose to vote early. There is also a big difference in early voting rates between municipalities, which range from 18.12 to $75.00 \%$.

\section{Multivariate analyses}

The next step is to turn to the multivariate analyses and examine whether the independent variables affect the dependent variable: the level of early voting. The results are presented in Table 1.

In model 1, three demographic independent variables are included: average income, age of the electorate $(65+)$, and the level of the electorate born abroad. The average income variable is statistically significant, with a positive coefficient. Accordingly, the findings indicate that municipalities with a higher average income have higher levels of early voting. Concerning the effect size, the results suggest that if the average income increases by one unit (1000 Swedish kronor), the level of early voting increases by $.034 \%$ units. The age variable is also positive and statistically 
Table 1 Multivariate regressions on early voting models $1-3$

\begin{tabular}{llll}
\hline & Model 1 & Model 2 & Model 3 \\
\hline Average income & $.034 * * *(.010)$ & $.045^{* * *}(.010)$ & $-.012 * * *(.003)$ \\
Age of the electorate $(65+)$ & $1.170^{* * *}(.097)$ & $.814 * * *(.088)$ & $-.047 * *(.007)$ \\
Level of electorate born abroad & $.290^{* * *}(.056)$ & $.322^{* * *}(.051)$ & $.026^{* *}(.011)$ \\
Rural municipalities & & $5.770^{* * *}(.335)$ & $1.245^{* * *}(.350)$ \\
Accessibility & & $3.624 * * *(.361)$ & $1.269 * *(.545)$ \\
LDV early voting at $t-1$ & 1159 & & $.737 * * *(.051)$ \\
Number of observations & 290 & 1159 & 868 \\
Number of municipalities & .377 & 290 & 290 \\
Adjusted $R^{2}$ & .000 & .508 & .764 \\
Sig & & .000 & .000 \\
\hline
\end{tabular}

Entries are the unstandardised regression coefficients with panel-corrected standard errors in parentheses **Significant at the .05 level; ***significant at the .01 level

significant, and the results predict that if the level of older people $(65+)$ increases by $1 \%$ unit, the level of early voting increases by $1.17 \%$ units. The third demographic variable, the level of the electorate born abroad, is also positive and statistically significant, and the results indicate that if the level of the electorate born abroad increases by $10 \%$ units, the level of early voting increases by $2.9 \%$ units.

In model 2, the variables rural municipalities and accessibility are added to the model. All three variables that were included in model 1 are still statistically significant, with positive coefficients. The dummy variable for rural municipalities is positive and statistically significant, and the results suggest that the level of early voting is $5.77 \%$ units higher in rural municipalities than in urban municipalities. The coefficient for the variable accessibility is also positive and statistically significant, and the results predict that if the number of early voting sites per one thousand eligible voters increases by one unit, the level of early voting increases by $3.6 \%$ units. In model 3, the lagged dependent variable is included with the other five independent variables. ${ }^{6}$ The variables average income and age of the electorate $(65+)$ are still statistically significant, but the signs of the coefficients have changed and become negative, which is unexpected. The variable level of electorate born abroad is still statistically significant, with a positive coefficient. The dummy variable rural municipalities and the variable accessibility are also still positive and statistically significant. As expected, when the lagged dependent variable is included, the size of the coefficients decreases; the size of the coefficient decreases to 1.245 for the dummy rural municipalities variable, and the coefficient for the accessibility variable decreases to 1.269 .

\footnotetext{
6 In model 3, the lagged dependent variable is included, which means that the panel for 2006 is dropped for the dependent variable, and the model therefore consists of 868 cases. To control the results for the 868 cases without the lagged dependent variable, I ran model 2 with the 868 cases. In that regression, all five independent variables are statistically significant and all coefficients have positive signs. Accordingly, the results do not alter if model 2 consists of 1159 cases or 868 cases.
} 
To summarise, the results show that the level of early voting is higher in municipalities where the average income is higher; where the level of older people is higher; where the level of the electorate born abroad is higher; in rural municipalities; and in municipalities where the number of early voting sites per one thousand eligible voters is higher. However, when the lagged dependent variable is included, the coefficients for average income and age $(65+)$ change, becoming negative, which indicates that these two variables are not as robust as the other three independent variables are for determining early voting.

To check whether the results from the multivariate models are robust, I did several robustness checks. To examine whether it was problematic (for example, with biased coefficients) that the dependent variable was bounded between 0 and 100, I transformed the dependent variable into an unbounded measure: logarithm. ${ }^{7}$ Then, I repeated the three multivariate models and compared the results from the original models (with the bounded dependent variable). The results were similar when the unbounded measure of the dependent variable was used to when the bounded measure of the dependent variable was used.

I also checked the robustness of the results by controlling for whether influential cases affect the results of the multivariate models. I used Cook's distance (Cook's D) for locating influential cases. To control the influential cases' impact on the regression, the most influential cases were removed, and the multivariate regressions were repeated; the results from the regressions (original models and control models) were then compared. Running the multivariate models without including the most influential cases did not alter the results.

\section{Conclusion}

In this study, I examined what characteristics affect early voting in Sweden, and a large-N study of all of Sweden's 290 municipalities for the four most recent elections was conducted. The results are in line with several previous findings. But what about the theoretical explanations of the results? Some of the results are easier to explain theoretically than others. Explaining the causal link between accessibility and early voting is straightforward. If early voting locations are more numerous and more accessible, the cost of voting decreases and therefore early voting is higher in municipalities with more early voting sites. The link between rural municipalities and early voting is also easy to explain. In rural municipalities, voters have a longer distance to travel to the polling places and therefore the cost of voting is higher for them than for voters in urban municipalities (Dyck and Gimpel 2005; Karp and Banducci 2000). However, if rural voters can combine voting with other errands, the cost of voting decreases and therefore voters in rural municipalities vote early to a greater degree than voters in urban municipalities. The theoretical link regarding why the level of early voting is higher in municipalities with a higher level of older people is also clear. Older voters can have problems getting to the polls on the

\footnotetext{
7 The logit transformation is the natural log.
}

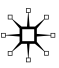


Election Day, for example due to a lack of public transport or if they are feeling ill. However, if voting is more flexible and people can vote early, the chance that older voters will get assistance to travel to the polls increases, and they can also choose to vote on a day when they are feeling well. Therefore, municipalities with a higher level of older citizens have a higher level of early voting.

I cannot establish a theoretical explanation of why the level of early voting is higher in municipalities with higher socio-economic standards by using the data and the analysis from this study. In Sweden it is not more complicated to vote early than to vote on the Election Day, so I do not find the explanation that people with a higher level of cognitive recourses are better equipped intellectually to use complicated early voting procedures and therefore are likely to vote early more often than others (see Garnett 2019, for example), to be relevant to the Swedish context. I can speculate that people living in municipalities with higher socio-economic standards have a richer cultural life and are often busier during the weekends, for example visiting sports events, travelling, or visiting their holiday cottage. Therefore, as the Election Day is on a Sunday, people living in these kinds of municipalities with higher socio-economic standards vote early to a greater extent than voters living in municipalities with lower socio-economic standards. However, this is only speculation and is not supported by any empirical findings from this study. Another possible explanation of why early voting is higher in municipalities with higher socio-economic standards is that it simply reflects the fact that turnout for any form of voting is higher in these kinds of municipalities.

Several studies have found that early voting mobilises disadvantaged citizens. The results from this study are similar, and it shows that if the level of the electorate born abroad increases, the level of early voting also increases. I cannot draw any conclusions from the data used in this study regarding why early voting is higher in municipalities where the level of foreign-born people is higher. Some previous studies have suggested the mobilisation of campaigns as a possible explanation of why disadvantaged groups such as people with an ethnic minority background and foreign-born people vote early more often than others (see, for example, Miller and Chaturvedi 2018; Stein and Garcia-Monet 1997). The suggestion that parties use campaigns to encourage particular groups of people to vote early may be one explanation of the positive effect of this in Sweden too, but this is only speculation and is not supported by any empirical evidence. Clearly, this is a question that needs further investigation.

As mentioned above, several studies in different contexts have found that similar factors affect the level of early voting. However, some of the suggested causal mechanisms are vague, and clearly there needs to be further research to establish more trustworthy causal links between early voting and some of its determinants. For example, to get a better understanding of why disadvantaged groups vote early more often than other voters, it may be relevant to use methodological tools such as surveys and interviews in future research to establish more trustworthy causal links.

Finally, one of the most important results of this study is that early voting in the Swedish municipalities is higher in those municipalities where there are more voting locations. If the goal of the municipalities is to increase early voting, any policy recommendation that is based on the results of this study should ensure that there are 
numerous early voting sites in the municipalities and if there are not, the municipalities should consider increasing the number of early voting sites they provide.

Funding This study was not founded by any grant.

Data availability The datasets generated during the current study are available from the corresponding author on reasonable request.

\section{Compliance with ethical standards}

Conflict of interest The author states that there is no conflict of interest.

\section{Appendix}

See Tables 2 and 3.

Table 2 Descriptive statistics for the independent variables

\begin{tabular}{lrcll}
\hline Independent variable & Mean & SD & Min & Max \\
\hline Average income & 263.06 & 42.67 & 188.50 & 593.40 \\
Age of the electorate $(+65)$ & 28.08 & 4.76 & 14.70 & 42.40 \\
Level of electorate born abroad & 12.09 & 6.74 & 2.70 & 49.27 \\
Rural/ural municipalities & .15 & .353 & 0 & 1 \\
Accessibility & .59 & .607 & .07 & 5.00 \\
\hline
\end{tabular}

Table 3 Correlation matrix-four independent variables

\begin{tabular}{lllll}
\hline Variable & Average income & $\begin{array}{l}\text { Age of the } \\
\text { electorate } \\
(65+)\end{array}$ & $\begin{array}{l}\text { Level of elector- } \\
\text { ate born abroad }\end{array}$ & Accessibility \\
\hline Average income & 1 & & & \\
Age of the electorate $(65+)$ & $-.088^{* * *}$ & 1 & & \\
Level of electorate born abroad & $.221^{* * *}$ & $-.342^{* * *}$ & 1 & 1 \\
Accessibility & $-.133^{* * *}$ & $.460^{* * *}$ & $-.155^{* * *}$ & 1 \\
\hline
\end{tabular}

***Correlation is significant at the .01 level (2-tailed)

\section{References}

Beck, N., and J.N. Katz. 1995. What to do (and not to do) with time-series cross-section data. American Political Science Review 89(3): 634-647.

Beck, N., and J.N. Katz. 1996. Nuisance versus substance: Specifying and estimating time-seriescross-section models. Political Analysis 6(1): 1-36.

Blais, A., A. Dobrzynska, and P. Loewen. 2007. Potential impacts of extended advance voting on voter turnout. Working paper series. Elections Canada.

Brewer, P., and S. Venaik. 2014. The ecological fallacy in national culture research. Organization Studies 35(7): 1063-1086. 
Brothén, M. (ed.). 2003. Svenska poströstare. Göteborg: Statsvetenskapliga institutionen: Göteborgs universitet.

Dahlberg, S., H. Oscarsson, and R. Öhrvall. 2008. Förtida röstning i Sverige. Göteborg: Statsvetenskapliga institutionen: Göteborgs universitet.

Downs, A. 1957. An economic theory of democracy. New York: Harper \& Row.

Dyck, J.J., and J.G. Gimpel. 2005. Distance, turnout, and the convenience of voting. Social Science Quarterly 86(3): 531-548.

Ersson, S., and J. Wide. 2001. Valdeltagandet i Sverige: Variation i tid och rum. In Rösträtten 80 år, ed. C. Jönsson, 149-168. Stockholm: Justitiedepartementet.

Finseraas, H., and K. Vernby. 2014. A mixed blessing for the left? Early voting, turnout and election outcomes in Norway. Electoral Studies 33: 278-291.

Garnett, H.A. 2019. Early voting: Comparing Canada, Finland, Germany, and Switzerland. Election Law Journal: Rules, Politics, and Policy 18(2): 116-131.

Gronke, P., and D. Krantz Toffey. 2008. The psychological and institutional determinants of early voting. Journal of Social Issues 64(3): 503-524.

Gronke, P., E. Galanes-Rosenbaum, and P.A. Miller. 2007. Early voting and turnout. PS Political Science \& Politics 40(4): 639-645.

Herlitz, E. 1985. Poströstningens utveckling och villkor i Sverige. Förvaltningsrättslig Tidskrift 2: 79-82.

Herron, M.C., and D.A. Smith. 2014. Race, party, and the consequences of restricting early voting in Florida in the 2012 general election. Political Research Quarterly 67(3): 646-665.

Högström, J. 2013. Quality of democracy around the globe: A comparative study. Department of Social Sciences, Mid Sweden University, Östersund.

Karp, J.A., and S.A. Banducci. 2000. Going postal: How all-mail elections influence turnout. Political Behavior 22(3): 223-239.

Karp, J.A., and S.A. Banducci. 2001. Absentee voting, mobilization, and participation. American Politics Research 29(2): 183-195.

Kropf, M.E. 2012. Does early voting change the socio-economic composition of the electorate? Poverty \& Public Policy 4(1): 1-19.

Lago, I., and A. Blais. 2019. Early voting and satisfaction with vote choice. Representation. https:// doi.org/10.1080/00344893.2019.1592013.

Lidström, A. 2016. Swedish local and regional government in a european context. In The oxford handbook of Swedish politics, ed. Jon Pierre, 414-428. New York: Oxford University Press.

Lijphart, A. 1999. Patterns of democracy: Government forms and performance in thirty-six democracies. New Haven: Yale University Press.

McAllister, I., and D. Muller. 2018. Early voting, election campaigning and party advantage in Australia. Electoral Studies 52: 103-110.

Miller, P., and N.S. Chaturvedi. 2018. Get out the early vote: Co-ethnic mobilization and convenience voting. Journal of Elections, Public Opinion and Parties 28(4): 399-423.

Neeley, G.W., and L.E. Richardson. 2001. Who is early voting? An individual level examination. The Social Science Journal 38(3): 381-392.

Oliver, J.E. 1996. The effects of eligibility restrictions and party activity on absentee voting and overall turnout. American Journal of Political Science 40(2): 498-513.

Richardson Jr., L.E., and G.W. Neeley. 1996. The impact of early voting on turnout: The 1994 elections in Tennessee. State and Local Government Review 28(3): 173-179.

Riker, W.H., and P.C. Ordeshook. 1968. A theory of the calculus of voting. American Political Science Review 62(1): 25-42.

Rojas, A., and D. Muller. 2014. Early voting in Australian federal elections: Causes and consequences. In Paper presented at the Australian Political Studies Association Annual Conference. Sydney: University of Sydney.

Rosenstone, S.J., and J. Hansen. 1993. Mobilization, participation, and democracy in America. New York: Macmillan Publishing Company.

Statistics Sweden. 2019. www.scb.se. Accessed 4 June 2019.

Stein, R.M. 1998. Introduction: Early voting. The Public Opinion Quarterly 62(1): 57-69.

Stein, R.M., and P.A. Garcia-Monet. 1997. Voting early but not often. Social Science Quarterly 78(3): 657-671.

Stein, R.M., and G. Vonnahme. 2011. Voting at non-precinct polling places: A review and research agenda. Election Law Journal: Rules, Politics, and Policy 10(3): 307-311. 
The Swedish Election Authority. 2019. www.val.se. Accessed 11 October 2019.

Verba, S., and N.H. Nie. 1972. Participation in America: Political democracy and social equality. New York: Harper \& Row.

Walker, H.L., M.C. Herron, and D.A. Smith. 2019. Early voting changes and voter turnout: North Carolina in the 2016 general election. Political Behavior 41(4): 841-869.

Publisher's Note Springer Nature remains neutral with regard to jurisdictional claims in published maps and institutional affiliations.

John Högström is Associate Professor in political science and is currently working at Mid Sweden University in Sweden. 